\title{
Drug Reaction with eosinophilia and systemic symptoms with alopecia universalis and vitiligo
}

\author{
Reação a drogas com eosinofilia e sintomas sistêmicos associada a alopecia \\ universal e vitiligo
}

Ives Alexandre Y. Koseki ${ }^{1}$ (D), Débora Sarzi Sartori ${ }^{1}$ (D), Isabelle Maffei Guarenti ${ }^{1}$ (D), Fábio Yutani Koseki ${ }^{1}$ (D), Amanda Dagostim Gietner ${ }^{2}$ (D), Simoni Euzébio Nunes² (D),

\begin{abstract}
Drug reactions with eosinophilia and systemic symptoms (DRESS) are rare and potentially fatal adverse hypersensitivity reaction to some drugs, especially anticonvulsants. The syndrome affects not only the skin but also other organs, especially the liver. The incidence can vary from 1 to 5 cases per 10.000 patients exposed to anticonvulsants. The recognition of the syndrome is of fundamental importance since the mortality rate is between 10 and $40 \%$. Once the diagnosis is established, the triggering drug must be identified and discontinued. Corticosteroids are usually associated with therapy. Autoimmune sequelae have been reported, including vitiligo and rarely alopecia. Alopecia universalis is a variant of alopecia areata, characterized by hair loss throughout the body. We report a case of DRESS, associated with two autoimmune dermatological diseases: alopecia universalis and vitiligo.
\end{abstract}

KEYWORDS: Drug hypersensitivity, Eosinophilia, Anticonvulsants, Drug eruptions.

\begin{abstract}
RESUMO
A reação a drogas com eosinofilia e sintomas sistêmicos (DRESS) é uma rara e potencialmente fatal reação adversa de hipersensibilidade, decorrente de alguns medicamentos, principalmente os anticonvulsivantes. A síndrome não afeta apenas a pele, mas também outros órgãos, principalmente o fígado. A incidência pode variar de 1 a 5 casos por 10.000 pacientes expostos aos anticonvulsivantes. O reconhecimento da síndrome é de fundamental importância devido a taxa de mortalidade entre 10-40\%. Uma vez estabelecido o diagnóstico, deve-se identificar o medicamento desencadeante e suspendê-lo. O corticosteróide geralmente é associado na terapia. Sequelas autoimunes foram relatadas, incluindo vitiligo e raramente alopecia. A alopecia universal é uma variante da alopecia areata, caracterizada pela perda de pelos em todo o corpo. Relatamos um caso de DRESS, associado a duas doenças autoimunes dermatológicas: alopecia universal e vitiligo.
\end{abstract}

PALAVRAS-CHAVE: Hipersensibilidade a drogas, Eosinofilia, anticonvulsivantes, Erupção por drogas.

\section{CLINICAL CASE}

Male patient, 22 years old, smoker and user of illicit drugs, had started with generalized clonic tonic seizures. The patient started phenobarbital and, after two months without seizure control, phenytoin was associated. Fourteen days later, he developed an exanthema in the face with generalized cranio-caudal progression, alopecia universalis, and fever. He progressed with generalized exfoliative dermatitis, pruritus, and trachyonychia. Laboratory tests showed changes in liver enzy- mes, leukocytosis with eosinophilia and atypical lymphocytes. He was transferred to a secondary hospital, where he was diagnosed with Stevens-Johnson syndrome (SJS) and discharged after 2 months with sodium valproate. After 5 days, the lesions and fever became worse. He sought assistance and was referred to our hospital. He presented with diffuse lymphadenomegaly, feverish, disseminated erythematous-scaly lesions, achromic and hypochromic spots on the face and limbs, alopecia universalis and trachyonychia. There was no mucosal involvement or epidermal detach-

\footnotetext{
Federal University of Pelotas / EBSERH. Pelotas, (RS), Brasil

University of the Extreme South of Santa Catarina Criciúma, (SC), Brasil.
} 
ment. The exams showed leukocytosis $(33,160)$ without right or left shift, eosinophilia (20\%), normal kidney and liver function. The hypothesis of DRESS was raised and systemic corticosteroid therapy was started. Serology for HTLV, HIV, HBsAg, HCV, CMV and Epstein-Barr were negative.
The anatomopathological examination showed mild perianexial mononuclear inflammatory lymphocytic infiltrate and absence of atypias. The patient had resolution of exfoliative dermatitis and alopecia and progressive improvement of vitiligo (figure 01).
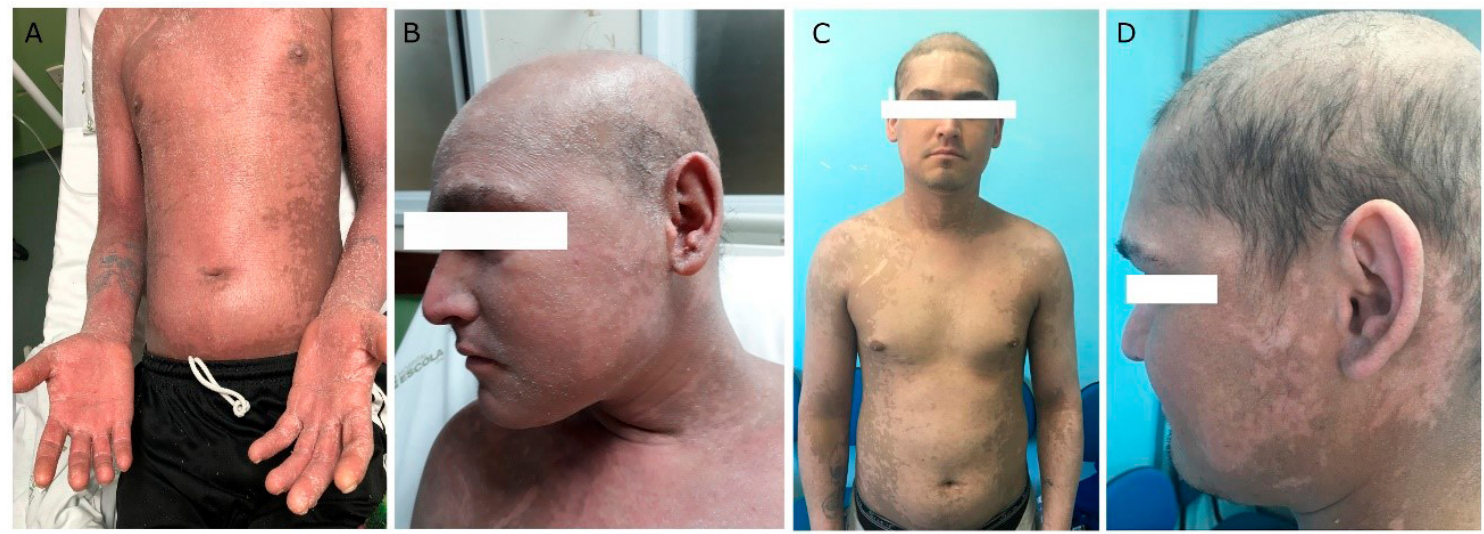

Figure 01 - Erythroderma and alopecia universalis in activity (A, B) and, 12 days later, in remission (C, D) associated with vitiligo.

\section{DISCUSSION}

The syndrome can cause the reactivation of several viruses of the herpes group, and the human herpes virus type 6 is the most frequent (70\% of cases). ${ }^{1}$ Unfortunately, it was not possible to perform this examination in the case presented due to the hospital limitations.

The DRESS is much more common than Stevens-Johnson syndrome (SJS) or toxic epidermal necrolysis (TEN). ${ }^{2}$ The clinical picture usually begins 2 to 8 weeks after exposure to the drug. ${ }^{3}$ The latency period between exposure and the onset of symptoms is longer in cases of DRESS than in most other drug reactions, usually occurring between 4 to 28 days in cases of SJS/TEN. ${ }^{1}$ Cross-sensitivity among risk with anticonvulsant medications may occur. ${ }^{1}$

The disease begins with a symmetrical morbilliform eruption and it cannot be differentiated clinically from an exanthematic drug eruption. ${ }^{1}$ Generalized exfoliative dermatitis or erythroderma occurs in $30 \%$ of cases and diffuse lymphadenopathy in $30-60 \%$ of cases. ${ }^{4}$ DRESS is related to the involvement of at least one organ in $90 \%$ of cases with the liver being the most common site. ${ }^{4}$ Fever was documented in $90 \%$ of cases. The presence of eosinophilia (more than $700 / \mathrm{microL}$ ) increases suspicion. ${ }^{4}$ The presence of lymphocytosis and atypical lymphocytes can occur (67\% of cases). ${ }^{4}$ Histological findings are nonspecific. ${ }^{4}$ Due to the presence of exfoliative dermatitis and lymphadenomegaly upon the patient's arrival at our service, a biopsy was important to exclude other diagnoses such as Mycosis Fungoides.

The first step in the treatment is the identification and withdrawal of the triggering drug, associated with supportive therapy. Systemic steroids are mainly indicated in cases with signs of severity. ${ }^{1,4}$ Among autoimmune diseases, the following are described: Graves' disease, Hashimoto's thyroiditis, type I diabetes mellitus, systemic lupus erythematosus, hemolytic anemia, vitiligo and rarely alopecia. ${ }^{5}$

\section{REFERENCES}

1. Shiohara T, Mizukawa Y. Drug-induced hypersensitivity syndrome (DiHS)/drug reaction with eosinophilia and systemic symptoms (DRESS): An update in 2019. Allergol Int. 2019;68(3):301-308. doi:10.1016/j. alit.2019.03.006

2. Shiohara T, Mizukawa Y. Drug-induced hypersensitivity syndrome (DiHS)/drug reaction with eosinophilia 
and systemic symptoms (DRESS): An update in 2019. Allergol Int. 2019;68(3):301-308. doi:10.1016/j. alit.2019.03.006

3. Kardaun $\mathrm{SH}$, Sidoroff A, Valeyrie-Allanore L, et al. Variability in the clinical pattern of cutaneous side-effects of drugs with systemic symptoms: does a DRESS syndrome really exist? $\mathrm{Br} J$ Dermatol. 2007;156(3):609-611. doi:10.1111/j.1365-2133.2006.07704.x
4. Duong TA, Valeyrie-Allanore $L$, Wolkenstein $P$, Chosidow O. Severe cutaneous adverse reactions to drugs. Lancet. 2017;390(10106):1996-2011. doi:10.1016/S01406736(16)30378-6

5. Kano $Y$, Tohyama M, Aihara $M$, et al. Sequelae in 145 patients with drug-induced hypersensitivity syndrome/drug reaction with eosinophilia and systemic symptoms: Survey conducted by the Asian Research Committee on Severe Cutaneous Adverse Reactions (ASCAR). J Dermatol. 2015;42(3):276-282. doi:10.1111/1346-8138.12770.

\section{Without financial support.}

\section{Contribution autor:}

IAYK - autor

DSS - co-autor

IMG - co-autor

FYK - co-autor

ADG - traductor

SEN - traductor

Author contact:

Ives Alexandre Y. Koseki

ives.alexandre@hotmail.com

Editor:

Prof. Dr. Felipe Villela Gomes

Received in: dec 16, 2020

Approved in: feb 12, 2021 